\title{
Article
}

\section{Shift from Acquisitive to Conservative Root Resource Acquisition Strategy Associated with Increasing Tree Age: A Case Study of Fraxinus mandshurica}

\author{
Zuwang Li, Zhi Liu, Guoqiang Gao, Xinlei Yang and Jiacun Gu *(D)
}

check for

updates

Citation: Li, Z.; Liu, Z.; Gao, G.;

Yang, X.; Gu, J. Shift from Acquisitive

to Conservative Root Resource

Acquisition Strategy Associated with

Increasing Tree Age: A Case Study of Fraxinus mandshurica. Forests 2021, 12,

1797. https://doi.org/10.3390/

f12121797

Academic Editors: Liming Yin, Peng Wang and Maire Holz

Received: 20 November 2021 Accepted: 14 December 2021

Published: 17 December 2021

Publisher's Note: MDPI stays neutral with regard to jurisdictional claims in published maps and institutional affiliations.

Copyright: (c) 2021 by the authors. Licensee MDPI, Basel, Switzerland. This article is an open access article distributed under the terms and conditions of the Creative Commons Attribution (CC BY) license (https:/ / creativecommons.org/licenses/by/ $4.0 /)$.
Key Laboratory of Sustainable Forest Ecosystem Management-Ministry of Education, School of Forestry, Northeast Forestry University, Harbin 150040, China; 17839785117@163.com (Z.L.); liuzhi1632018@163.com (Z.L.); gaoguoqiang_nefu@163.com (G.G.); 15373308091@163.com (X.Y.)

* Correspondence: gjcnefu@163.com; Tel.: +86-451-82190614; Fax: +86-451-82191044

\begin{abstract}
Tree age has an important effect on the form and function of fine roots. Previous studies have focused on the variations in root morphological and chemical traits among tree ages, while less attention has been given to the physiological traits, impeding a full understanding of the relationship between root resource acquisition strategy and tree age. Here, we measured root morphological (diameter, specific root length, specific root area and tissue density), chemical (nitrogen concentration) and physiological (respiration and exudation rate) traits of young, middle-aged and mature trees of Fraxinus mandshurica in a temperate secondary forest in northeastern China. Our overall aim was to determine how root traits and related resource acquisition strategy change with tree age. The results showed that from young to mature trees, root diameter gradually increased, but specific root length, specific root area, root nitrogen concentration, respiration and exudation rates all decreased, and the significant differences were mainly found between young and mature trees. Pearson's correlation analysis revealed that the relationships of root respiration and exudation rates to root morphological and chemical traits depended on tree age and the specific traits examined, but these correlations were all significant except for root tissue density when the data were pooled across all tree age classes. Principal component analysis (PCA) showed that the conservative traits represented by root diameter, and the acquisitive traits such as root respiration and exudation rates and related morphological and chemical traits, occupied two ends of the first axis, respectively, while root tissue density occupied one end of the second axis, partially confirming the conceptual framework of "root economics space". Standardized major axis (SMA) analysis of root exudation and respiration rates showed that young trees allocated more root carbon flux to the formation of root exudation, compared to middle-aged and mature trees. Our findings suggest that root resource acquisition strategy in F. mandshurica appears to shift from an absorptive to conservative strategy associated with increasing tree age, which may have substantial consequences for individual growth and interspecific competition, as well as belowground carbon allocation in ecosystems.
\end{abstract}

Keywords: tree age; ontogenetic development; root resource acquisition strategy; root exudation; root respiration; belowground $\mathrm{C}$ allocation

\section{Introduction}

Fine roots (diameter $\leq 2 \mathrm{~mm}$ ) in trees are the main organ for absorbing soil resources; thus, their functional traits have profound impacts on individual performance and ecological processes [1-3]. According to the variations in fine root traits, the strategy of root resource acquisition can be subdivided into two categories: acquisitive (or competitive) and conservative [4,5]. The former usually characterizes thinner root diameter (RD), larger specific root length (SRL), specific root area (SRA), respiration rate (RR) and exudation rate (RE), which may be beneficial for exploiting soil resources efficiently [4-6]. By contrast, the latter exhibits thicker RD and smaller SRL, RR and RE. Some studies have shown that root 
resource acquisition strategy tends to adjust during the development of trees, as manifested by changes in root traits. For example, Rosenvald et al. [7] found in Betula pendula plantations that SRL and SRA both decreased, while RD and root tissue density (RTD) increased with increasing stand age. Another study, on Pinus tabulaeformis and Robinia pseudoacacia, also showed that the carbon $(\mathrm{C})$, nitrogen $(\mathrm{N})$ and $\mathrm{C} / \mathrm{N}$ of fine roots (diameter $<2 \mathrm{~mm}$ ) in $R$. pseudoacacia increased with increasing stand age [8]. However, previous studies mostly focused on the variations in root morphology and chemistry among the stand or tree ages [9]; less is known about root physiological traits, such as root respiration and exudation [4].

Root respiration is a key physiological trait that provides necessary energy for other metabolic activities such as nutrient absorption $[10,11]$. Root exudates mainly contain organic acids, sugars and amino acids and play an important role in promoting the decomposition of soil organic matter and N mineralization [12-15]. Several studies have confirmed that RR and RE changed significantly with increasing stand age. For instance, Gong et al. [16] found that RR of poplar decreased with increasing stand age. Li et al. [17] demonstrated that the RE of a 9-year-old Picea asperata plantation was significantly greater than those of 13-year-old and 31-year-old stands. Regardless of tree age, some studies suggested a positive correlation between RR and RE [18-20], but others confirmed a trade-off between them [21]. In recent, Ataka et al. [22] found that less $C$ was allocated to $R E$ than RR (i.e., lower slope of regression equation between them) under 5-year $\mathrm{N}$ enrichment in a Quercus crispula secondary forest. However, it is not clear how the relationship between RE and $\mathrm{RR}$, as well as related root $\mathrm{C}$ allocation, change with tree aging.

Mounting evidence suggests that RR and RE are closely linked to root morphological and chemical traits in woody plants [23-25]. For example, Jia et al. [23] found that RD, SRL and root $\mathrm{N}$ concentration (RN) could explain $81-93 \%$ of the variation in RR in F. mandshurica and Larix gmelinii plantations. Sun et al. [18] also showed that RN was significantly correlated with RR and RE in both Quercus serrata and Quercus glauca secondary forests. On the other hand, Li et al. [26] reported a significant negative correlation between RE and SRL in a Betula platyphylla plantation. However, as root traits tended to change with increasing tree age [8], it thus remains to be explored which traits are consistently linked to RR and RE across tree age classes.

In this study, we measured RR and RE in young (4-10 years), middle-aged (30-50 years), and mature (70-90 years) trees of Fraxinus mandshurica in a natural secondary forest in northeastern China. Concurrently, five key root traits of morphology (RD, SRL, RTD, and SRA) and chemistry (RN) were determined. We focused on the lower order roots, as they are the main body of absorptive fine roots, governing nutrient and water uptake. The main aims were to reveal how RR, RE, and other root traits varied with tree age, and to explore how root $C$ was allocated to respiration and exudation processes, and finally, to illustrate the potential change in root resource acquisition strategy. Specifically, we tested the following hypotheses: (1) RR and RE of F. mandshurica should decrease in association with increasing tree age [16,17]; (2) The relationships of RR and RE to other root traits should be consistent across all tree age classes [18,22]. (3) There is a positive correlation between RR and RE, but more $C$ flux would be allocated to RE in young trees, compared with middle-aged and mature trees $[17,22]$.

\section{Materials and Methods}

\subsection{Study Site}

The research was carried out at the Maoershan Forest Ecosystem Research Station $\left(45^{\circ} 20^{\prime} \mathrm{N}, 127^{\circ} 30^{\prime} \mathrm{E}\right.$, with an average elevation of $\left.400 \mathrm{~m}\right)$ of Northeast Forestry University in Heilongjiang Province, China. The site has a continental temperate monsoon climate with a mean annual temperature of $3.1^{\circ} \mathrm{C}$. The monthly mean temperature is $-18.5^{\circ} \mathrm{C}$ in January, and $22.0^{\circ} \mathrm{C}$ in July. The annual precipitation varies from 600 to $800 \mathrm{~mm}$, and precipitation is concentrated from June to September during the growing season [27]. The main vegetation type at the study site is a natural secondary forest, where dominant tree 
species are F. mandshurica, Juglans mandshurica, Betula platyphylla, Acer mono, and Ulmus davidiana var. japonica. Three $20 \mathrm{~m} \times 30 \mathrm{~m}$ plots were set randomly in a stand in midJuly 2020, and stand characteristics were quantified concurrently. The stem density was $2360 \pm 201$ trees $^{-1}$; detailed information on the sampled trees and soil characteristics are shown in Table 1.

Table 1. Characteristics of sampled trees and soils (0-10 cm depth) in Fraxinus mandshurica at different ages.

\begin{tabular}{|c|c|c|c|c|c|c|c|}
\hline $\begin{array}{l}\text { Ontogenetic Stage } \\
\text { (Tree Age (Years)) }\end{array}$ & $\begin{array}{c}\text { Mean } \\
\text { DBH/Ground } \\
\text { Diameter } \\
(\mathrm{Cm})\end{array}$ & $\begin{array}{l}\text { Mean Height } \\
\text { (M) }\end{array}$ & Soil Ph & $\begin{array}{l}\text { Total Soil } \\
\text { Carbon } \\
\left(\mathrm{G} \mathrm{Kg}^{-1}\right)\end{array}$ & $\begin{array}{l}\text { Total Soil } \\
\text { Nitrogen } \\
\left(\mathrm{G} \mathrm{Kg}^{-1}\right)\end{array}$ & $\begin{array}{c}\text { Soil Total } \\
\text { Available } \\
\text { Nitrogen } \\
\left(\mathrm{Mg} \mathrm{Kg}^{-1}\right)\end{array}$ & $\begin{array}{c}\text { Soil } \\
\text { Available } \\
\text { Phosphorus } \\
\left(\mathrm{Mg} \mathrm{Kg}^{-1}\right)\end{array}$ \\
\hline Young (4-10) & $2.17 \pm 0.41$ & $0.64 \pm 0.08$ & $5.55 \pm 0.06 b$ & $66.44 \pm 6.22 b$ & $4.79 \pm 0.43 b$ & $24.54 \pm 2.20 \mathrm{a}$ & $7.93 \pm 1.35 a$ \\
\hline Middle-aged (30-50) & $16.26 \pm 1.80$ & $17.16 \pm 1.61$ & $5.51 \pm 0.10 \mathrm{~b}$ & $151.44 \pm 14.81 \mathrm{a}$ & $12.05 \pm 0.99 a$ & $24.48 \pm 1.45 \mathrm{a}$ & $9.65 \pm 1.81 \mathrm{a}$ \\
\hline Mature (70-90) & $35.46 \pm 0.82$ & $24.97 \pm 1.69$ & $6.08 \pm 0.13 a$ & $149.93 \pm 21.89 a$ & $12.23 \pm 1.69 a$ & $25.94 \pm 1.92 \mathrm{a}$ & $7.94 \pm 1.23 a$ \\
\hline
\end{tabular}

Note: Ground diameters were measured only for young trees. Values are mean $\pm 1 \mathrm{SE}(n=5)$. Different lower-case letters indicate significant differences $(p<0.05)$ among tree age classes.

\subsection{Trees Selection and Root Sampling}

We selected young, middle-age and mature trees from the secondary forest using a comprehensive method. First, we randomly selected trees at different ages depending on experience, such as by observing and measuring the diameter at breast height (or ground diameter) and tree height. Secondly, for the middle-aged and mature trees, we applied a growth cone to determine the tree ages by counting the number of growth rings. Thirdly, for the young trees, we cut off stem segments following root trait measurements, and then estimated individual ages by observing the growth rings of stem cross-sections with a biological microscope (Olympus Electronics Inc., Tsukuba, Japan) equipped with a Motic 3000 CCD camera (Motic Corporation, Xiamen, China) in the laboratory. Based on the growth rhythm of $F$. mandshurica at the study site, we classified trees with age of 4-10 years, 30-50 years, and 70-90 years into young, middle-aged, and mature tree groups, respectively. Each age class consisted of five individual trees. All sampled trees were in good growth, free of obvious disease, and distributed under similar site conditions.

Terminal fine roots of targeted trees were carefully excavated from the upper $10 \mathrm{~cm}$ of the soil mineral horizon by hand. All root samples were traced back to the target trees, or identified based on characteristics (e.g., diameter, branching pattern, and color) known to be unique to the targeted species in order to ensure that roots were from the targeted trees [28]. In this study, the first three orders of roots were used as the measurement unit, because they were generally absorptive roots according to previous anatomical observation $[29,30]$. The most distal root tips were labeled as first-order roots [31,32].

\subsection{Root Exudation Measurements}

Root exudates were collected using a syringe-based collection protocol [33] in lateJuly 2020. Firstly, the intact fine roots (i.e., roots still attached to the tree) were gently washed with deionized water to remove rhizosphere soil and free-living microbes without damaging the tissue. Secondly, the first three orders of roots from the same branch were put into a $50 \mathrm{~mL}$ syringe filled with acid-washed glass beads and $25 \mathrm{~mL} \mathrm{C}$-free nutrient solution $\left(0.2 \mathrm{mM} \mathrm{MgSO}_{4}, 0.3 \mathrm{mM} \mathrm{CaCl}_{2}, 0.2 \mathrm{mM} \mathrm{K}_{2} \mathrm{SO}_{4}, 0.1 \mathrm{mM} \mathrm{KH}_{2} \mathrm{PO}_{4}, 0.5 \mathrm{mM} \mathrm{NH}_{4} \mathrm{NO}_{3}\right)$. The syringes were wrapped by using tinfoil and covered with litterfall on the surface to prevent exposure to sunlight and heat. After the roots were incubated in the nutrient solution for $24 \mathrm{~h}$, we collected the nutrient solutions. Then, two more flushes of $10 \mathrm{~mL}$ nutrient solution were applied in order to obtain a full recovery of exudation C. Meanwhile, three syringes without root segments inside were processed in the exact same mode as the other syringes to serve as the control group. The recovered solutions were filtered using $0.22-\mu \mathrm{m}$ syringe filters (Jinteng, Tianjin, China) within $2 \mathrm{~h}$ after collection and stored at $-20{ }^{\circ} \mathrm{C}$ until analysis [28]. After collecting the recovered solutions, we also collected soils $(0-10 \mathrm{~cm}$ depth) near the roots (within $20 \mathrm{~cm}$ radius) for later determination of soil properties. 
In the laboratory, the total organic $\mathrm{C}$ in the solutions was analyzed on a TOC/TN analyzer (Multi N/C 2100s; Analytik, Jena, Germany) in non-purgeable C mode using potassium hydrogen phthalate as the standard. The total organic $C$ of each sample was calibrated by using the mean of the total organic $C$ of the control groups. $R E\left(\mathrm{mg} \mathrm{C} \mathrm{g}^{-1} \mathrm{~h}^{-1}\right)$ was calculated by dividing the calibrated total $\mathrm{C}$ by resident time in the syringes and root weight $[22,28]$.

\subsection{Root Respiration Measurements}

RR was measured with a closed static chamber system and GMP343 infrared gas analyzer (Vaisala, Vantaa, Finland) [18,34]. Following exudation collection, roots were immediately cut, washed with deionized water to remove any remaining nutrient solution and possible contaminant, and then had excess water removed from their surfaces with tissue paper. RR was measured within 15 min after root excising, and the data later than the first 5-min interval were used to eliminate errors associated with opening the chamber. The gas analyzer measured, and the GL220 data logger (Graphtec, Yokohama, Japan) recorded, $\mathrm{CO}_{2}$ concentrations in the chamber once per second. The chamber temperature was also recorded. We maintained stable chamber temperature with an incubator (at $17-19^{\circ} \mathrm{C}$, consistent with the concurrent soil temperature). The measured roots were stored separately in Ziploc bags in a cooler with ice $\left(0-4{ }^{\circ} \mathrm{C}\right)$ and transported back to the laboratory within $4 \mathrm{~h}$ for subsequent measurement of root morphological and chemical traits. RR (n mol CO $\mathrm{g}^{-1} \mathrm{~s}^{-1}$ ) was calculated as below [18]:

$$
\mathrm{RR}=\frac{1}{n} \times \sum_{i=1}^{n}\left(\frac{\mathrm{C}_{\mathrm{CO} 2}(t i+\Delta t)-\mathrm{C}_{\mathrm{CO} 2}(t i)}{\Delta t}\right) \times \frac{V_{s}}{22.4} \times \frac{273.2}{273.2+T} \times \frac{1000}{W}
$$

In the formula, $\mathrm{RR}$ is root respiration rate; $\mathrm{C}_{\mathrm{CO} 2}$ is the $\mathrm{CO}_{2}$ concentration (ppm) at a given time. The parameter $t i$ denotes the initial time, and $\Delta t$ denotes the time interval of RR measurements. $V_{S}$ is the volume of the chamber $(0.308 \mathrm{~L})$, and 22.4 is the volume of standard gas. $T$ is the temperature $\left({ }^{\circ} \mathrm{C}\right)$ in chamber during measurements, and $W$ is the dry mass $(\mathrm{g})$ of the root segments.

\subsection{Measurements of Root Morphological Traits}

In the laboratory, root samples were scanned with an Epson Expression 12000XL color scanner at 600 dpi (Epson Telford Ltd., Suwa Nagano, Japan). The mean diameter, total length, total surface area and volume of the roots were determined with root system analyzer software (WinRHIZO Pro 2016, Regent instruments Inc., Québec, QC, Canada). The scanned roots were placed in an oven at $65{ }^{\circ} \mathrm{C}$ to be dried to constant weight (accurate to $0.0001 \mathrm{~g}$ ). RD (mm), SRL (root length per unit dry mass, $\mathrm{m} \mathrm{g}^{-1}$ ), SRA (surface area per unit dry mass, $\mathrm{m}^{2} \mathrm{~kg}^{-1}$ ), and RTD (dry mass per unit volume, $\mathrm{g} \mathrm{cm}^{-3}$ ) were calculated.

\subsection{Measurements of Soil Properties and Root Nitrogen Concentration}

In the lab, each fresh soil sample was passed through a $2 \mathrm{~mm}$ sieve and separated into two subsamples. One subsample of $10.00 \mathrm{~g}$ fresh soil was extracted with $2 \mathrm{M} \mathrm{KCL}$ to determine soil ammonium $\left(\mathrm{NH}_{4}{ }^{+}-\mathrm{N}\right)$ and nitrate $\left(\mathrm{NO}_{3}{ }^{-}-\mathrm{N}\right)$ concentrations with a continuous flow analyzer (Auto Analyzer 3, SEAL Analytical GmbH, Norderstedt, Germany). Total available soil $\mathrm{N}$ concentration $\left(\mathrm{mg} \mathrm{kg}^{-1}\right)$ was calculated as the sum of the $\mathrm{NH}_{4}{ }^{+}-\mathrm{N}$ and $\mathrm{NO}_{3}{ }^{-}-\mathrm{N}$ concentrations. Another subsample was air dried and then used to determine soil $\mathrm{pH}$, available phosphorus (P), total soil C, and N concentrations. Available P concentration was determined from $5.00 \mathrm{~g}$ subsamples of air-dried soils, which were digested by $\mathrm{HCL}-\mathrm{H}_{2} \mathrm{SO}_{4}$, then analyzed with a continuous flow analyzer (Auto Analyzer 3, see details above). Soil pH was measured by an acidometer (MT-5000, Shanghai, China) [35]. Air-dried soils were passed through a $0.15 \mathrm{~mm}$ sieve, then total soil $\mathrm{C}$ and $\mathrm{N}$ concentrations were determined by a Macro Elemental Analyzer (vario MACRO cube, Elementar Analysensysteme $\mathrm{GmbH}$, Langenselbold, Germany) [36]. RN was also determined by the Macro Elemental Analyzer. 


\subsection{Data Analysis}

The mean values and standard errors $(n=5)$ of RD, SRL, SRA, RTD, RN, RR and RE of F. mandshurica, and $\mathrm{pH}$, total $\mathrm{C}$, total $\mathrm{N}$, total available $\mathrm{N}$, and available $\mathrm{P}$ concentrations of soils were calculated for each tree age class. All data met the normal distribution. The effect of tree age on the root traits was firstly tested using one-way ANOVA; if the effect was significant, then Fisher's protected LSD test was used to identify the statistical differences in root traits and soil characteristics among three tree age classes. Pearson's correlation was used to determine the potential relationships of root morphology and RN to RE and RR, and of root traits to soil $\mathrm{pH}$, total soil $\mathrm{C}$, and $\mathrm{N}$ concentrations. The relationship between $\mathrm{RE}$ and RR in each tree age class was tested by linear regression analysis after their units were unified as $\mathrm{mg} \mathrm{C} \mathrm{g}^{-1} \mathrm{~h}^{-1}$, and the potential difference in the slopes of regression models was tested by standardized major axis (SMA) analysis. Principal component analysis (PCA) was applied to determine the interrelationships among multiple root traits and to identify their adjustments to tree aging. For the analyses mentioned above, the significance level was set at $\alpha=0.05$. All statistical analyses were performed using SPSS (2010, V. 19.0, SPSS Inc., Cary, NC, USA), SMA regression analyses were performed using SMATR (Version 2.0, http:/ / www.bio.mq.edu.au/ecology/SMATR/, accessed on 29 July 2006) [37], and the PCA was performed using R 3.5.0 (R Core Development Team, http:/ / www.r-project.org/ accessed on 23 April 2018).

\section{Results}

\subsection{Root Morphological Traits}

SRL and SRA decreased and RTD remained stable, but RD in F. mandshurica increased with increasing tree age (Figure 1). Specifically, SRL of young trees was significantly 1.3-fold higher than those of middle-aged and mature trees, but not different between the latter two age classes. SRA of young trees was markedly 1.8-fold higher than those of the other two tree age classes. The difference in RD was only significant between young and mature trees, while no significant difference was found in RTD among tree age classes (Figure 1).
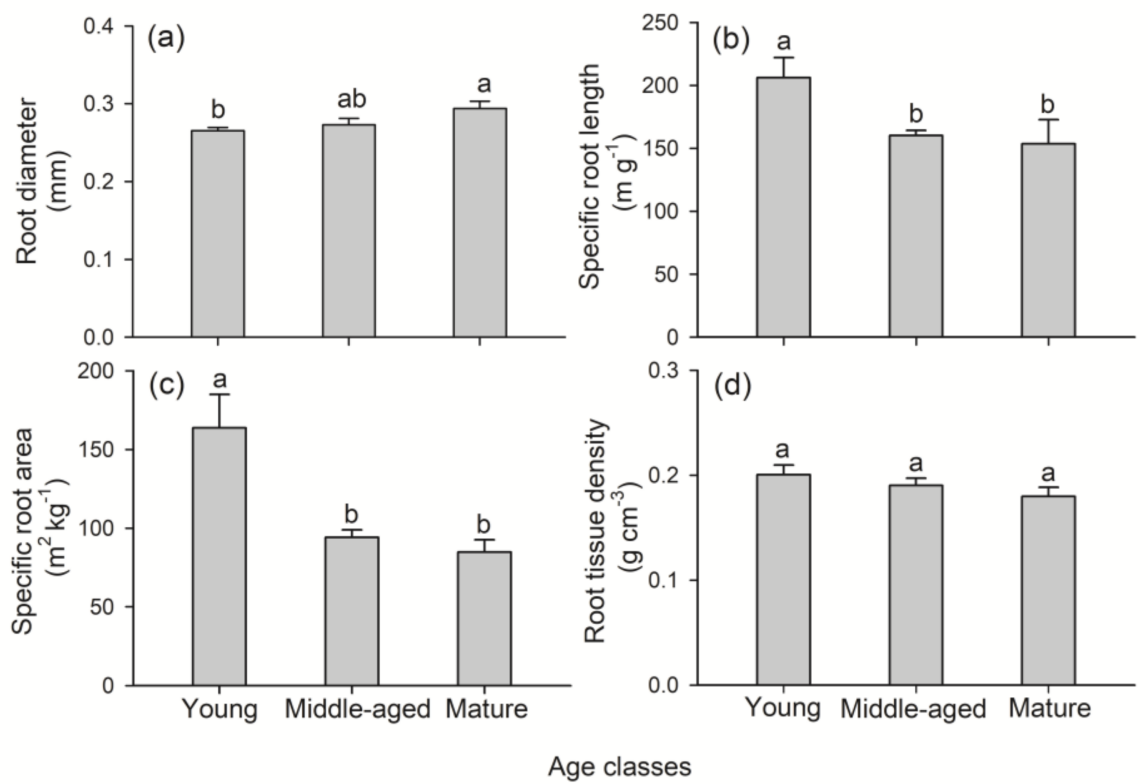

Figure 1. Root diameter (RD, (a)), specific root length (SRL, (b)), specific root area (SRA, (c)), and root tissue density (RTD, (d)) in Fraxinus mandshurica at different tree ages. Mean is shown as a bar, and $\mathrm{SE}$ as a whisker $(n=5)$. Different lower-case letters indicate significant differences $(p<0.05)$ among age classes in each panel. 


\subsection{Root N Concentration, Respiration and Exudation Rates}

$\mathrm{RN}, \mathrm{RR}$ and RE all decreased from young to mature trees (Figure 2). RN of trees at young age was significantly higher than those of trees at middle and mature ages, but no significant difference was shown between the latter two age classes (Figure 2a). RRs of young and middle-aged trees were significantly higher than that of mature trees, while there was no significant difference between the first two age classes (Figure 2b). For RE, young trees and mature trees showed significant differences, but they did not significantly differ from middle-aged trees (Figure 2c).
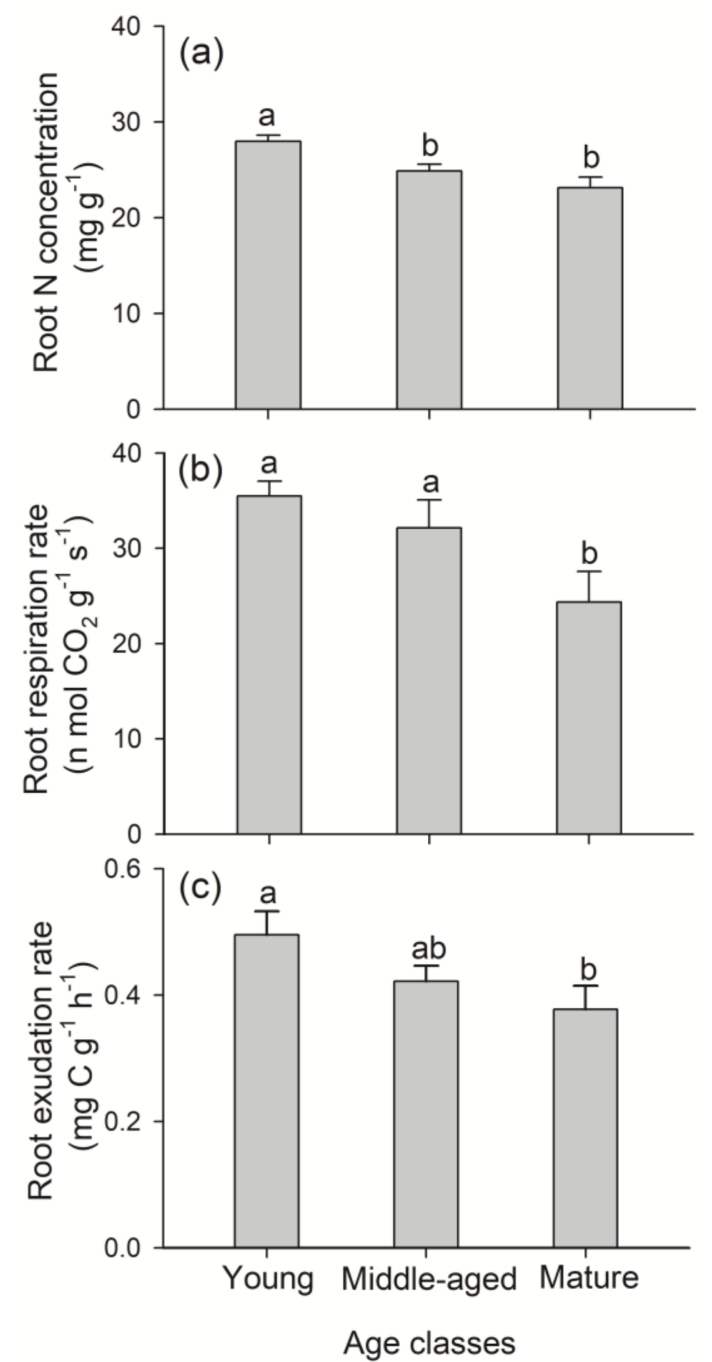

Figure 2. Root nitrogen concentration ( $R \mathrm{~N},(\mathbf{a}))$, root respiration rate (RR, (b)), and root exudation rate (RE, (c)) in Fraxinus mandshurica at different tree ages. Mean is shown as a bar, and SE as a whisker $(n=5)$. Different lower-case letters indicate significant differences $(p<0.05)$ among age classes in each panel.

\subsection{Linkages of Root Respiration and Exudation Rates to Root Morphological and Chemical Traits}

$\mathrm{RR}$ was generally correlated with root morphological and chemical traits in young and middle-aged trees, except for RN in the middle-aged class (Table 2). However, RR of mature trees was significantly correlated with SRA and RN (Table 2). Regardless of the significance level, RR was positively correlated with SRL, SRA and RN across all three age classes, but negatively correlated with RD and RTD. In comparison, the linkages between $\mathrm{RE}$ and other traits were more diverse, depending on tree age classes. RD and SRL of young trees, RN of middle-aged trees, and SRL of mature trees did not correlate with RE ( $p>0.05$, Table 2), while the correlations in other cases were all significant (Table 2). When the data 
were pooled across all age classes, both RR and RE were significantly correlated with other traits except for RTD (Table 2). Principal component analysis (PCA) revealed that the first two trait axes explained $75.8 \%$ and $13.8 \%$ of the total variance, respectively (Figure 3). RR, $\mathrm{RE}, \mathrm{RN}, \mathrm{SRL}$, and SRA were clustered at one end of the first axis, indicating the acquisitive syndromes, whereas RD belonging to conservative traits occupied the opposite end. RTD was orthogonal to the first axis, dominating the second axis (Figure 3). Apparently, root traits shifted from the left to the right side along the first axis with increasing tree age, indicating that young trees had more acquisitive root traits while the older ones possessed conservative traits.

Table 2. Relationships of root respiration and exudation rates to root morphological traits and root nitrogen concentration in Fraxinus mandshurica at different tree ages.

\begin{tabular}{|c|c|c|c|c|c|c|c|c|c|}
\hline \multirow{2}{*}{ Root Traits } & & \multicolumn{4}{|c|}{$\mathrm{RR}$ (n mol CO $\mathrm{CO}^{-1} \mathrm{~h}^{-1}$ ) } & \multicolumn{4}{|c|}{$\operatorname{RE}\left(\mathrm{mg} \mathrm{C} \mathrm{g}^{-1} \mathrm{~h}^{-1}\right)$} \\
\hline & & Young & Middle-Aged & Mature & All Ages & Young & Middle-Aged & Mature & All Ages \\
\hline \multirow{2}{*}{$\mathrm{RD}(\mathrm{mm})$} & $r$ & -0.89 & -0.94 & -0.85 & -0.93 & -0.74 & -0.90 & -0.91 & -0.84 \\
\hline & $p$ & 0.046 & 0.016 & 0.067 & $<0.001$ & 0.156 & 0.039 & 0.035 & $<0.001$ \\
\hline \multirow{2}{*}{$\operatorname{SRL}\left(\mathrm{m} \mathrm{g}^{-1}\right)$} & $r$ & 0.95 & 0.97 & 0.71 & 0.73 & 0.82 & 0.96 & 0.76 & 0.84 \\
\hline & $p$ & 0.012 & 0.005 & 0.177 & 0.002 & 0.088 & 0.011 & 0.137 & $<0.001$ \\
\hline \multirow{2}{*}{$\operatorname{SRA}\left(\mathrm{m}^{2} \mathrm{~kg}^{-1}\right)$} & $r$ & 0.96 & 0.97 & 0.99 & 0.72 & 0.97 & 0.94 & 0.97 & 0.87 \\
\hline & $p$ & 0.010 & 0.005 & 0.002 & 0.001 & 0.005 & 0.018 & 0.007 & 0.011 \\
\hline \multirow{2}{*}{$\operatorname{RTD}\left(\mathrm{g} \mathrm{cm}^{-3}\right)$} & $r$ & -0.98 & -0.97 & -0.82 & -0.28 & -0.93 & -0.97 & -0.90 & -0.40 \\
\hline & $p$ & 0.004 & 0.007 & 0.088 & 0.309 & 0.024 & 0.008 & 0.039 & 0.135 \\
\hline \multirow{2}{*}{$\mathrm{RN}\left(\mathrm{mg} \mathrm{g}^{-1}\right)$} & $r$ & 0.98 & 0.76 & 0.94 & 0.89 & 0.89 & 0.84 & 0.97 & 0.91 \\
\hline & $p$ & 0.004 & 0.133 & 0.019 & $<0.001$ & 0.044 & 0.075 & 0.008 & $<0.001$ \\
\hline
\end{tabular}

Note: Abbreviations for root traits are shown in Figures 1 and 2. Significant correlations are indicated in bold type $(p<0.05)$.

\subsection{Relationship between Root Respiration Rate and Exudation Rate}

For each age class, there was a significant positive correlation between RR and RE $(p<0.05$, Table 3$)$. When the data were pooled across all age classes, RE still showed a significant positive correlation with RR ( $p<0.05$, Table 3$)$. Irrespective of tree age class, over $82 \%$ variation in RE could be explained by $R R$, and vice versa. Standardized major-axis (SMA) analysis showed that the regression slope of RE and RR was markedly larger in young trees (slope $=0.55$ ) than middle-aged (slope $=0.19$ ) and mature trees (slope $=0.27$ ), but a significant difference was only found between the young and middle-aged trees (Table 3). The SMA suggested that the greater proportion of root-derived $\mathrm{C}$ was allocated to RE than RR in young trees, in comparison with the other two age classes.

Table 3. Standardized major axis (SMA) analysis of root exudation rate (RE) and respiration rate (RR) in Fraxinus mandshurica at different tree ages $(n=5)$.

\begin{tabular}{ccccc}
\hline Ontogenetic Stage (Tree Age (Years)) & Slope & Intercept & $\boldsymbol{R}^{\mathbf{2}}$ & $\boldsymbol{p}$ \\
\hline Young (4-10) & $0.55 \mathrm{a}$ & -0.34 & 0.84 & $\mathbf{0 . 0 2 8}$ \\
Middle-aged (30-50) & $0.19 \mathrm{~b}$ & 0.15 & 0.94 & $\mathbf{0 . 0 0 7}$ \\
Mature (70-90) & $0.27 \mathrm{ab}$ & 0.09 & 0.95 & $\mathbf{0 . 0 0 5}$ \\
All ages & 0.26 & 0.11 & 0.82 & $\mathbf{0 . 0 2 2}$ \\
\hline
\end{tabular}

Note: RE was dependent variable (y), RR was independent variable (x). All data were converted into the same unit, i.e., $\mathrm{mg} \mathrm{C} \mathrm{g}^{-1} \mathrm{~h}^{-1}$. Significant regressions are indicated in bold type $(p<0.05)$. Different lower-case letters indicate significant differences $(p<0.05)$ in the slopes among ages $(n=5)$. 


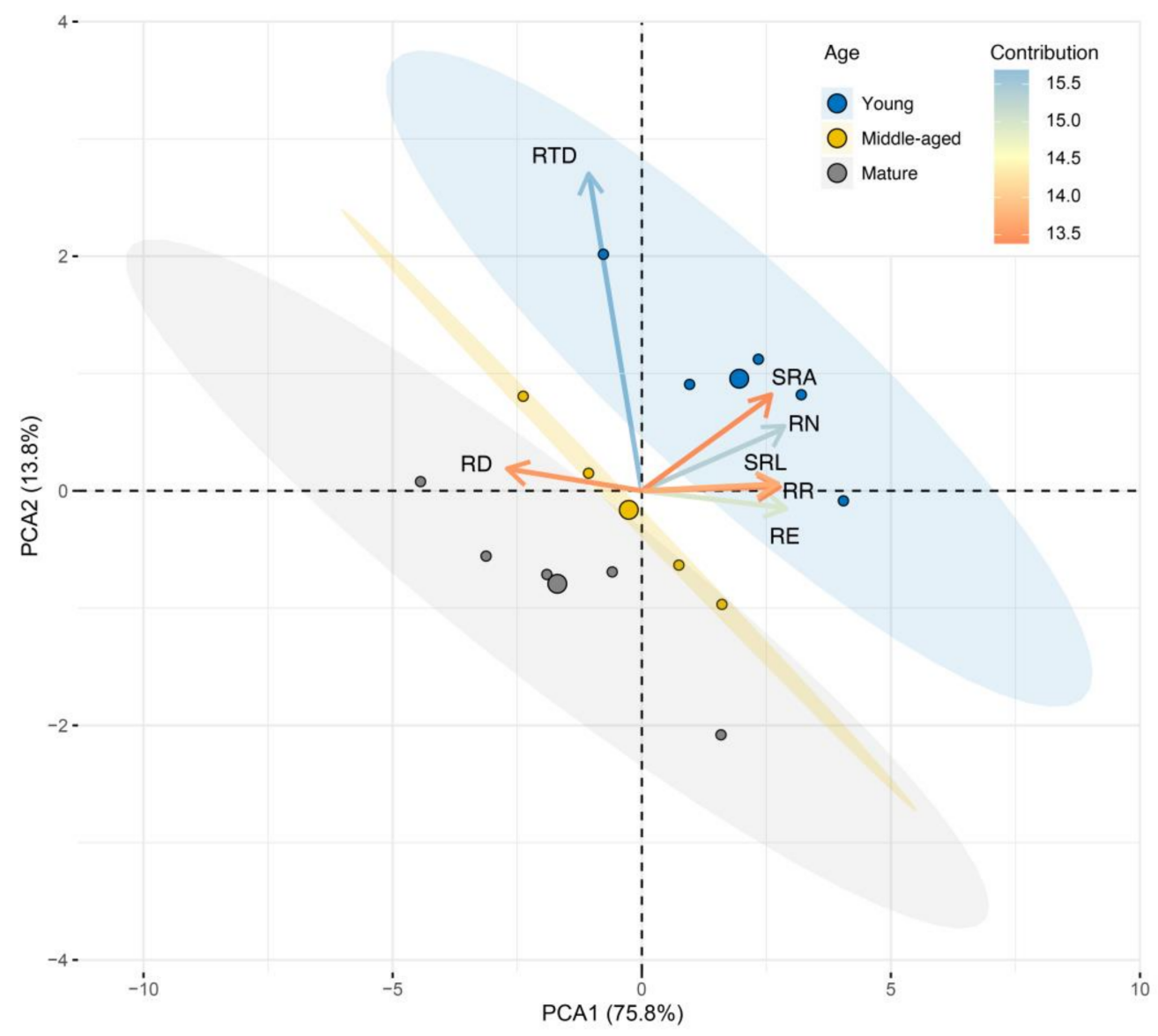

Figure 3. Principal component analysis (PCA) for root respiration rate (RR), root exudation rate (RE), root diameter (RD), root nitrogen concentration (RN), root tissue density (RTD), specific root length (SRL) and area (SRA) in Fraxinus mandshurica at different tree ages. Variables used for the PCA are shown with their vectors.

\section{Discussion}

\subsection{Variations of Root Traits Associated with Tree Age}

With increasing tree age, RR, RE, SRL, SRA and RN in F. mandshurica generally declined, and RD increased markedly, but RTD remained stable, supporting our first hypothesis. The changes in root morphological traits found here have been confirmed by previous studies. For example, Børja et al. [38] found that the SRL (diameter $<5 \mathrm{~mm}$ ) in a 30-year-old stand was significantly larger than those in 60-year-old and 120-year-old ones in Picea abies plantations. Li et al. [26] reported that with increasing stand age, RD (diameter $<2 \mathrm{~mm}$ ) increased, but SRL decreased significantly in Fraxinus velutina plantations on saline-alkali land. In a natural secondary forest, Rosenvald et al. [7] also confirmed that SRL of the first- and second-order roots of $B$. pendula decreased with increasing tree age. There are at least two possible reasons accounting for the shift of root morphology with tree aging in our study. For one, those young trees may need to build their root systems efficiently, compared with the older trees. In such a secondary forest, young trees generally live under the main canopy, thus must face greater survival pressures such as limited sunlight and soil resources. Given the stable RTD across all tree ages, the lower RD and greater SRL and SRA of individual roots in young trees mean they have a cost-saving way to extend total root length, thus to expand their foraging range [7]. Another reason is that roots with greater SRL and SRA generally have higher potential for resource uptake [39]. Therefore, young trees may have greater acquisition capacity at the individual root level to compensate for their relatively smaller whole root systems. In addition, RN of F. mandshurica decreased with increasing tree age, consistent with other studies $[40,41]$, 
which may reflect the associated decline in metabolic activity such as root respiration (see discussion below) [42].

In this study, RR in F. mandshurica decreased with increasing tree age (Figure 2), which was confirmed by previous studies [43,44]. For example, Gong et al. [16] found that the RR in a 5-year-old poplar plantation was significantly higher than in 10-year-old and 15-year-old plantations. This is possibly because the root systems of young trees are relatively younger and tender, and have more vigorous metabolic activity, such as nutrient absorption and exudation (as shown in our study). Some studies have reported that roots with smaller diameters tend to exhibit greater RR [45], which is confirmed by our results, i.e., young trees have thinner roots and corresponding higher RR. Similar to RR, RE also decreased significantly with increasing tree age (Figure 2), which is in line with other studies. For instance, Li et al. [17] found that RE in 9-year-old trees was significantly higher than in 13-year-old and 31-year-old trees in P. asperata plantations. In addition, the variations in RE among tree age classes may be related to trees' physiological status and nutritional requirements. As mentioned above, the young trees are physiologically vigorous and have greater growth potential, indicating their stronger demands for aboveground and belowground resources [10]. In the forest we studied, soil total $\mathrm{N}$ concentration around the roots of young trees was the lowest; higher RE may enable these trees to mobilize more soil nutrients to improve the availability [46]. However, Pearson's correlation analysis confirmed that no root traits other than RTD were correlated with soil properties showing differences among tree age classes (Table 4), indicating that the variations in these root traits were mainly caused by tree aging, or only slightly influenced by surrounding soils.

Table 4. Pearson's correlations between root traits and the total soil carbon, total soil nitrogen and soil $\mathrm{pH}$ when data were pooled across all tree ages $(n=15)$.

\begin{tabular}{|c|c|c|c|c|c|c|}
\hline \multirow[b]{2}{*}{ Fine Root Traits } & \multicolumn{2}{|c|}{$\begin{array}{l}\text { Total Soil Carbon } \\
\qquad\left(\mathrm{g} \mathrm{kg}^{-1}\right)\end{array}$} & \multicolumn{2}{|c|}{$\begin{array}{l}\text { Total Soil Nitrogen } \\
\qquad\left(\mathrm{g} \mathrm{kg}^{-1}\right)\end{array}$} & \multicolumn{2}{|c|}{ Soil pH } \\
\hline & $\begin{array}{c}\text { Correlation } \\
\text { Coefficient } \\
\qquad(r)\end{array}$ & $p$ & $\begin{array}{c}\text { Correlation } \\
\text { Coefficient } \\
\qquad(r)\end{array}$ & $p$ & $\begin{array}{c}\text { Correlation } \\
\text { Coefficient } \\
\qquad(r)\end{array}$ & $p$ \\
\hline $\mathrm{RR}\left(\mathrm{n} \mathrm{mol} \mathrm{CO} \mathrm{g}^{-1} \mathrm{~h}^{-1}\right)$ & -0.011 & 0.969 & -0.077 & 0.785 & -0.062 & 0.826 \\
\hline $\operatorname{RE}\left(\mathrm{mg} \mathrm{Cg}^{-1} \mathrm{~h}^{-1}\right)$ & -0.088 & 0.755 & -0.138 & 0.624 & 0.060 & 0.829 \\
\hline $\mathrm{RD}(\mathrm{mm})$ & -0.107 & 0.704 & -0.044 & 0.875 & 0.036 & 0.899 \\
\hline $\operatorname{SRL}\left(\mathrm{m} \mathrm{g}^{-1}\right)$ & -0.127 & 0.653 & -0.152 & 0.588 & 0.067 & 0.814 \\
\hline SRA $\left(\mathrm{m}^{2} \mathrm{~kg}^{-1}\right)$ & -0.473 & 0.075 & -0.500 & 0.058 & -0.105 & 0.709 \\
\hline $\operatorname{RTD}\left(\mathrm{g} \mathrm{cm}^{-3}\right)$ & -0.757 & 0.001 & -0.739 & 0.002 & -0.743 & 0.002 \\
\hline $\mathrm{RN}\left(\mathrm{mg} \mathrm{g}^{-1}\right)$ & -0.227 & 0.416 & -0.282 & 0.309 & -0.081 & 0.774 \\
\hline
\end{tabular}

Note: Abbreviations for root traits are shown in Figures 1 and 2. Significant correlations are indicated in bold type $(p<0.05)$.

\subsection{Relationships of Root Respiration and Exudation with Other Root Traits}

Variations in RR and RE among tree ages were also associated with changes in root morphological and chemical traits in F. mandshurica, but the statistical significance of their correlations differed among specific age classes (Table 2), partially supporting our second hypothesis. When data were pooled across all age classes, root morphological and chemical traits except for RTD were significantly correlated with RR and RE (Table 2), which is confirmed by some previous studies [47]. For example, Han et al. [6] collected data including RR and root chemical and morphological traits of 245 plant species worldwide, and found that RR was positively correlated with RN. Sun et al. [4] confirmed that RE was positively correlated with RN, SRL and SRA, but negatively correlated with RD among 18 woody species in subtropical forests. We also noted that the correlations of RR and RE with other root traits were not significant for a specific age class, such as their relations to RN in middle-aged trees. Nonetheless, irrespective of the significant level, we found the directions of that correlations between root trait pairs were consistent across all age classes, indicating their inherent functional relations. 
To our knowledge, this is the first study to report the comprehensive relationships among root functional traits in particular with physiological traits associated with tree age variations, which may improve our understanding of changes in fine root resource acquisition strategy along the ontogenetic stage. The PCA showed that those traits related to resource uptake, such as SRL, SRA, RN, RR, and RE, were mainly distributed on one end of the first axis, while RD related to construction cost was on the other end in $F$. mandshurica (Figure 3). In addition, we found that root acquisitive traits tend to be higher for young trees, indicating their potentially stronger capacity for resource absorption and competition at the individual root level $[18,29]$. On the contrary, $R D$ as a conservative trait was much greater in middle-aged and mature trees. These results suggest that the change in root resource acquisition strategy from acquisitive to conservative was associated with increasing tree age in F. mandshurica, confirming that the "root economics spectrum" shown among species [48] still exists within a species that is induced by individual development.

Moreover, we found that RTD was the only trait orthogonal to the axis of the "economics spectrum", and was almost independent of tree age. Thus, our results indicate that variations in root functional traits among tree ages are multidimensional [49]. However, our findings only partially support the conceptual framework of "root economics space" formed by multiple plant species [50], which consists of a classical fast-slow "conservation" gradient formed by RTD and RN, and an orthogonal "collaboration" gradient that ranges from "do-it-yourself" resource uptake (larger SRL) to "outsourcing" of resource uptake to mycorrhizal fungi (thicker RD). In the current study, RN was not consistent with the prediction of "root economics space" (i.e., negative to RTD). The variability of root traits caused by tree age is inherently associated with intraspecific variation, which may differ from the interspecific variation patterns to some degree [48]. We acknowledge that our results must be constrained by the limited number of sampling trees and species, as well as the range of tree age; thus, the universality of our findings needs to be tested by extensive research on other tree species in the future.

\subsection{Root-Derived C Allocation to Root Respiration and Exudation}

$\mathrm{RE}$ and RR are two critical physiological processes in root systems; however, their relationship has seldom been investigated in trees of different ages. In this study, RE and RR were significantly positively correlated across all age classes (Figure 3; Table 3). The regression slopes of these two traits were quite similar between middle-aged and mature trees, but all of them were significantly lower than that of young trees, partially supporting our third hypothesis. Several previous studies have shown that RE was positively correlated with RR in a deciduous-evergreen mixed forest [4], a secondary broad-leaved forest [18], and a secondary forest [22], which is consistent with our results. Such positive correlation may be attributable to two possible reasons. Firstly, partial root exudates are actively released through ion channels and vesicles, in which required energy is provided by root respiration [45]. Secondly, greater root exudation may stimulate microbial activities, and consequently promote the decomposition of soil organic matter, thus ultimately improving the availability of soil nutrients. Rich nutrients may conversely stimulate the absorption by roots, leading to higher demand for energy supplied by root respiration (about 20-25\% of the total) [51,52]. Collectively, the positive correlation between RR and RE was constant along the ontogenetic stage, which not only reflects their close relationship in terms of energy utilization and provision, but also indicates the coordination in physiological functions, i.e., maximizing resource acquisition.

In our study, the regression slope of exudation-respiration in young trees was the largest (Table 3), indicating that more $\mathrm{C}$ was allocated to root exudates in young trees than in middle-aged and mature trees. As root respiration could provide energy for the processes of both root exudation and absorption [51,52], the lower slope of root exudationrespiration in the older trees of $F$. mandshurica means more energy was possibly used for nutrient uptake. Such results may also reflect the shift in resource acquisition strategy from younger to older trees, because the older ones mainly depend on direct nutrient 
absorption, rather than on indirect nutrient mobilization, by increasing root exudation as the younger trees do. On the other hand, the different priorities of $C$ utilization may be related to soil nutrient availability at different ages. Although there was no significant difference in available $\mathrm{N}$ and $\mathrm{P}$ concentrations in bulk soils among tree ages, soil total $\mathrm{N}$ and $C$ concentrations at young age were significantly lower than in the other two age classes (Table 1). This indicated that young trees may face deficient nutrient pools. As discussed above, root exudation could promote rhizosphere microbial activities and then mobilize soil nutrients, which ultimately improves the soil nutrient accessibility of roots [46]. Therefore, young trees might selectively deploy greater $C$ to root exudation in order to promote their nutrient absorption. Conversely, there were higher total soil $\mathrm{N}$ concentrations in middleaged and mature trees, leading to a lower ratio of root exudation to root respiration. Our results are consistent with a previous study in Quercus crispula under 5-year $\mathrm{N}$ addition, which showed that a lower proportion of $C$ was allocated into root (i.e., the first three orders) exudation in fertilization treatment in comparison with the control [22].

\section{Conclusions}

The study on fine root functional traits, particularly of RR and RE in F. mandshurica at different ages, demonstrated a systematic trend of root traits associated with increasing tree age, in which SRL, SRA, RN, RR and RE all decreased, but RD increased and RTD remained stable from young to mature trees. There were tight linkages between $R R$ and RE and those morphological and chemical traits, despite the degree to which they varied with tree age. RD represented the conservative trait, while RR, RE, SRL and RN indicated the acquisitive syndromes. Thus, it seems that a "root economics spectrum" exists along the ontogenetic stage, in which young trees exhibit acquisitive root traits but mature trees are conservative. Interestingly, RTD is orthogonal to the axis of the root economics spectrum, partially supporting the conceptual framework of "root economics space". Moreover, young trees deployed more root-derived C to RE than RR compared with mature trees, further confirming the age-related shift of root acquisition strategy. Although limited to by number of tree species, our results may provide insight into the strategies of root resource uptake and $C$ allocation during ontogenetic development, as well as the dynamics of temperate secondary forests.

Author Contributions: Conceptualization, J.G. and Z.L. (Zuwang Li); methodology, Z.L. (Zuwang Li), G.G. and Z.L. (Zhi Liu); software, Z.L. (Zhi Liu); validation, J.G. and Z.L. (Zuwang Li); formal analysis, Z.L. (Zuwang Li); investigation, Z.L. (Zuwang Li), Z.L. (Zhi Liu) and X.Y.; data curation, Z.L. (Zuwang Li); writing — original draft preparation, Z.L. (Zuwang Li); writing-review and editing, Z.L. (Zuwang Li), G.G. and J.G.; visualization, Z.L. (Zuwang Li); project administration, J.G. All authors have read and agreed to the published version of the manuscript.

Funding: This research was supported by the National Natural Science Foundation of China (31870608) and by the Fundamental Research Funds for the Central Universities (2572018BA11).

Data Availability Statement: The data are included in the article.

Acknowledgments: The authors thank Dongnan Wang, Hao Ren, Yaoyuan Ma, and Hanxuan Fu for their help with field and laboratory work, as well as the Maoershan Forest Ecosystem Research Station for logistic support in the field.

Conflicts of Interest: The authors declare no conflict of interest.

\section{References}

1. Laliberte, E. Below-ground frontiers in trait-based plant ecology. New Phytol. 2017, 213, 1597-1603. [CrossRef] [PubMed]

2. Bardgett, R.D.; Mommer, L.; De Vries, F.T. Going underground: Root traits as drivers of ecosystem processes. Trends Ecol. Evol. 2014, 29, 692-699. [CrossRef] [PubMed]

3. Gao, G.; Liu, Z.; Wang, Y.; Wang, S.; Ju, C.; Gu, J. Tamm review: Fine root biomass in the organic (O) horizon in forest ecosystems: Global patterns and controlling factors. For. Ecol. Manag. 2021, 491, 119-208. [CrossRef]

4. Sun, L.; Ataka, M.; Han, M.; Han, Y.; Gan, D.; Xu, T.; Guo, Y.; Zhu, B. Root exudation as a major competitive fine-root functional trait of 18 coexisting species in a subtropical forest. New Phytol. 2021, 229, 259-271. [CrossRef] [PubMed] 
5. Ma, Z.; Guo, D.; Xu, X.; Lu, M.; Bardgett, R.D.; Eissenstat, D.M.; McCormack, M.L.; Hedin, L. Evolutionary history resolves global organization of root functional traits. Nature 2018, 555, 94-97. [CrossRef] [PubMed]

6. Han, M.; Zhu, B. Linking root respiration to chemistry and morphology across species. Glob. Change Biol. 2021, $27,190-201$. [CrossRef] [PubMed]

7. Rosenvald, K.; Ostonen, I.; Uri, V.; Varik, M.; Tedersoo, L.; Lõhmus, K. Tree age effect on fine-root and leaf morphology in a silver birch forest chronosequence. Eur. J. For. Res. 2013, 132, 219-230. [CrossRef]

8. Chen, L.; Deng, Q.; Yuan, Z.; Mu, X.; Kallenbach, R.L. Age-related C:N:P stoichiometry in two plantation forests in the Loess Plateau of China. Ecol. Eng. 2018, 120, 14-22. [CrossRef]

9. Jagodziński, A.M.; Ziółkowski, J.; Warnkowska, A.; Prais, H. Tree age effects on fine root biomass and morphology over chronosequences of Fagus sylvatica, Quercus robur and Alnus glutinosa stands. PLoS ONE 2016, 11, e0148668. [CrossRef] [PubMed]

10. Bouma, T.J.; Yanai, R.D.; Elkin, A.D.; Hartmond, U.; Alva, D.E.; Eissenstat, D.M. Estimating age-dependent costs and benefits of roots with contrasting life span: Comparing apples and oranges. New Phytol. 2001, 150, 685-695. [CrossRef]

11. Lambers, H.; Chapin, F.S.; Pons, T.L. Respiration. In Plant Physiological Ecology, 2nd ed.; Lambers, H., Chapin, F.S., Pons, T.L., Eds.; Springer: New York, NY, USA, 2008; Volume 3, pp. 101-150.

12. Chai, Y.N.; Schachtman, D.P. Root exudates impact plant performance under abiotic stress. Trends Plant Sci. 2021, in press. [CrossRef] [PubMed]

13. Keller, A.B.; Brzostek, E.R.; Craig, M.E.; Fisher, J.B.; Phillips, R.P. Root-derived inputs are major contributors to soil carbon in temperate forests, but vary by mycorrhizal type. Ecol. Lett. 2021, 24, 626-635. [CrossRef]

14. Walker, T.S.; Bais, H.P.; Vivanco, G. Root exudation and rhizosphere biology. Plant Physiol. 2003, 132, 44-51. [CrossRef]

15. Williams, A.; De Vries, F.T. Plant root exudation under drought: Implications for ecosystem functioning. New Phytol. 2020, 225, 1899-1905. [CrossRef]

16. Gong, J.; Ge, Z.; An, G.; Duan, Q.; You, X.; Huang, Y. Soil respiration in poplar plantations in northern China at different forest ages. Plant Soil. 2012, 360, 109-122. [CrossRef]

17. Li, J.; Jiang, X.; Yin, H.; Yin, C.; Wei, Y.; Liu, Q. Root exudates and soil microbes in three Picea asperata plantations with different stand ages. Chin. J. Appl. Ecol. 2014, 25, 325-332.

18. Sun, L.; Ataka, M.; Kominami, Y.; Yoshimura, K. Relationship between fine-root exudation and respiration of two Quercus species in a Japanese temperate forest. Tree Physiol. 2017, 37, 1011-1020. [CrossRef] [PubMed]

19. Stovall, J.P.; Seiler, J.R.; Fox, T.R. Respiratory C fluxes and root exudation differ in two full-sib clones of Pinus taeda (L.) under contrasting fertilizer regimes in a greenhouse. Plant Soil. 2013, 363, 257-271. [CrossRef]

20. De Vries, F.T.; Williams, A.; Stringer, F.; Willcocks, R.; McEwing, R.; Langridge, H.; Straathof, A.L. Changes in root-exudateinduced respiration reveal a novel mechanism through which drought affects ecosystem carbon cycling. New Phytol. 2019, 224, 132-145. [CrossRef]

21. Hill, P.; Kuzyakov, Y.; Jones, D.; Farrar, J. Response of root respiration and root exudation to alterations in root C supply and demand in wheat. Plant Soil. 2007, 291, 131-141. [CrossRef]

22. Ataka, M.; Sun, L.; Nakaji, T.; Katayama, A.; Hiura, T. Five-year nitrogen addition affects fine root exudation and its correlation with root respiration in a dominant species, Quercus crispula, of a cool temperate forest, Japan. Tree Physiol. 2020, 40, 367-376. [CrossRef] [PubMed]

23. Jia, S.; McLaughlin, N.B.; Gu, J.; Li, X.; Wang, Z. Relationships between root respiration rate and root morphology, chemistry and anatomy in Larix gmelinii and Fraxinus mandshurica. Tree Physiol. 2013, 33, 579-589. [CrossRef] [PubMed]

24. Yang, L.; Wang, X.; Mao, Z.; Jiang, Z.; Gao, Y.; Chen, X.; Aubrey, D.P. Root exudation rates decrease with increasing latitude in some tree species. Forests 2020, 11, 1045. [CrossRef]

25. Mori, S.; Hagihara, A. Root respiration in Chamaecyparis obtusa trees. Tree Physiol. 1991, 8, 217-225. [CrossRef] [PubMed]

26. Li, Y.; Wang, X.; Zhou, J.; Wei, H.; Du, Z. Fine root distribution and activity of Fraxinus velutina plantations based on the forest stand age in the Yellow River Delta. J. Arid Land Resour. Environ. 2020, 34, 171-177.

27. Jin, Y.; Wang, C.; Zhou, Z. Conifers but not angiosperms exhibit vulnerability segmentation between leaves and branches in a temperate forest. Tree Physiol. 2018, 85, 141-147. [CrossRef]

28. Yin, H.; Wheeler, E.; Phillips, R.P. Root-induced changes in nutrient cycling in forests depend on exudation rates. Soil Biol. Biochem. 2014, 78, 213-221. [CrossRef]

29. Wang, Y.; Li, Z.; Wang, Z.; Gu, J. Functional trait plasticity but not coordination differs in absorptive and transport fine roots in response to soil depth. Forests 2020, 11, 42. [CrossRef]

30. Guo, D.; Xia, M.; Wei, X.; Chang, W.; Liu, Y.; Wang, Z. Anatomical traits associated with absorption and mycorrhizal colonization are linked to root branch order in twenty-three Chinese temperate tree species. New Phytol. 2008, 180, 673-683. [CrossRef]

31. Pregitzer, K.S.; Deforest, L.J.; Burton, J.A.; Allen, F.M.; Ruess, W.R.; Hendrick, L.R. Fine root architecture of nine north American trees. Ecol. Monogr. 2002, 2, 293-309. [CrossRef]

32. McCormack, M.L.; Dickie, I.A.; Eissenstat, D.M.; Fahey, T.J.; Fernandez, C.W.; Guo, D.; Helmisaari, H.; Hobbie, E.A.; Iversen, C.M.; Jackson, R.B.; et al. Redefining fine roots improves understanding of below-ground contributions to terrestrial biosphere processes. New Phytol. 2015, 207, 505-518. [CrossRef]

33. Phillips, R.P.; Erlitz, Y.; Bier, R.; Bernhardt, E.S. New approach for capturing soluble root exudates in forest soils source. Funct Ecol. 2008, 6, 990-999. [CrossRef] 
34. Makita, N.; Hieano, Y.; Dannoura, D.; Kominami, Y.; Mizoguchi, T.; Ishii, H.; Kanazawa, Y. Fine root morphological traits determine variation in root respiration of Quercus serrata. Tree Physiol. 2009, 29, 579-585. [CrossRef]

35. Wang, W.; Wang, Y.; Hoch, G.; Wang, Z.; Gu, J. Linkage of root morphology to anatomy with increasing nitrogen availability in six temperate tree species. Plant Soil. 2018, 425, 189-200. [CrossRef]

36. Gao, G.; Goebel, M.; Wang, Y.; Wang, Z.; Gu, J. Spatial-temporal variations of absorptive fine roots in the organic and soil layers of a Larix gmelinii forest. Trees 2021, 35, 1013-1023. [CrossRef]

37. Falster, D.S.; Wavid, I.W.; Wright, I.J. User's guide to smatr: Standardised major axis tests and routines version 2.0, copyright 2006. Biol. Rev. 2006, 81, 259-291.

38. Børja, I.; De Wit, H.A.; Steffenrem, A.; Majdi, H. Stand age and fine root biomass, distribution and morphology in a Norway spruce chronosequence in southeast Norway. Tree Physiol. 2008, 28, 773-784. [CrossRef]

39. Wang, Y.; Dong, X.; Wang, H.; Wang, Z.; Gu, J. Root tip morphology, anatomy, chemistry and potential hydraulic conductivity vary with soil depth in three temperate hardwood species. Tree Physiol. 2016, 36, 99-108. [CrossRef] [PubMed]

40. Nan, H.; Liu, Q.; Xiao, Q. Root foraging ability of spruce (Picea asperata) in two growth stages. Chin. J. Appl. Environ. Biol. 2015, 21, 547-554.

41. Yang, Z.; Song, S.; Li, J.; Li, H.; Luo, Z. A study on root characteristics and nutrients of different aged Larix principis-rupprechtii Mayr. plantations. Acta Bot. Boreali-Occident. Sin. 2014, 34, 1432-1442.

42. Gargallo-Garriga, A.; Sardans, J.; Pérez-Truiillo, M.; Rivas-Ubach, A.; Oravec, M.; Vecerova, K.; Urban, O.; Jentsch, A.; Kreyling, J.; Beierkuhnlein, C.; et al. Opposite metabolic responses of shoots and roots to drought. Sci. Rep. 2014, 4, 6829. [CrossRef] [PubMed]

43. Kong, D.; Fridley, J.D. Does plant biomass partitioning reflect energetic investments in carbon and nutrient foraging? Funct. Ecol. 2019, 33, 1627. [CrossRef]

44. Kurosawa, Y.; Mori, M.; Ferrio, J.P.; Yamaji, K.; Koyama, K.; Haruma, T.; Doyama, K. Initial burst of root development with decreasing respiratory carbon cost in Fagus crenata Blume seedlings. Plant Species Biol. 2020, 36, 146-156. [CrossRef]

45. Freschet, G.T.; Pagès, L.; Iversen, C.; Comas, L.; Rewald, B.; Roumet, C.; Klimešová, J.; Zadworny, M.; Poorter, H.; Postma, J.; et al. A starting guide to root ecology: Strengthening ecological concepts and standardizing root classification, sampling, processing and trait measurements. New Phytol. 2020, 232, 973-1122. [CrossRef] [PubMed]

46. Meier, I.C.; Finzi, A.C.; Phillips, R.P. Root exudates increase N availability by stimulating microbial turnover of fast-cycling N pools. Soil Biol. Biochem. 2017, 106, 119-128. [CrossRef]

47. Burton, A.J.; Jarvvey, A.C.; Jarvi, M.P.; Pregitzer, K.S. Chronic N deposition alters root respiration-tissue N relationship in northern hardwood forests. Glob. Change Biol. 2015, 18, 258-266. [CrossRef]

48. Kramer-Walter, K.R.; Bellingham, P.J.; Millar, T.R.; Smissen, R.D.; Richardson, S.J.; Laughlin, D.C. Root traits are multidimensional: Specific root length is independent from root tissue density and the plant economic spectrum. J. Ecol. 2016, 104, 1299-1310. [CrossRef]

49. Weemstra, M.; Mommer, L.; Visser, E.; Ruijven, J.; Kuyper, T.W.; Mohren, G.; Sterck, F. Towards a multidimensional root trait framework: A tree root review. New Phytol. 2016, 211, 1159-1169. [CrossRef]

50. Bergmann, J.; Weigelt, A.; Plas, F.; Laughlin, D.C.; Kuyper, T.W.; Guerrero-Ramirez, N.; Iversen, C.M.; Kattge, J.; McCormack, M.L.; Meier, I.C.; et al. The fungal collaboration gradient dominates the root economics space in plants. Sci. Adv. 2020, 6, eaba3756. [CrossRef]

51. Lambers, H.; Atkin, O.K.; Millenaar, F.F. Respiratory patterns in roots in relation to their functioning. In Plant Roots: The Hidden Half, 3rd ed.; Waisel, Y., Eshel, A., Kafkaki, U., Eds.; Marcel Dekker, Inc.: New York, NY, USA, 2002; Volume 3, pp. 521-552.

52. Lambers, H.; Chapin, F.S.; Pons, T.L. Life Cycles: Environmental influences and adaptations. In Plant Physiological Ecology, 2nd ed.; Lambers, H., Chapin, F.S., Pons, T.L., Eds.; Springer: New York, NY, USA, 2008; Volume 11, pp. 375-402. 